\title{
THE IMPORTANCE OF SELF-ESTEEM TO STUDENTS LEARNING RESPONSIBILITIES AND GROUP LEARNING COMMITMENT OF PHYSICAL EDUCATION STUDENTS
}

\author{
Jusuf Blegur ${ }^{1)}$, Zuvyati A. Tlonaen ${ }^{2)}$, Andreas J. F. Lumba ${ }^{3)}$, Julian J. Leko ${ }^{4)}$ \\ 1) Universitas Kristen Artha Wacana, Kupang, Indonesia \\ E-mail: jusufblegur@ukaw.ac.id \\ 2) Universitas Kristen Artha Wacana, Kupang, Indonesia \\ E-mail: zuvyatitlonaen@ukaw.ac.id \\ 3) Universitas Kristen Artha Wacana, Kupang, Indonesia \\ E-mail: andreaslumba@ukaw.ac.id \\ 4) Universitas Kristen Artha Wacana, Kupang, Indonesia \\ E-mail: julianleko@ukaw.ac.id
}

\begin{abstract}
This study aims to examine the relationship between self-esteem and learning responsibility and group learning commitment of physical education students. We used a quantitative approach, with a correlation design. During the research, there were 88 physical education students from semester VI involved. In collecting the data, we used the State Self-Esteem Scale from Heatherton and Polivy (1991), the Personal Responsibility Questionnaire from Mergler (2007), and the Organization Commitment Scale from Allen and Meyer (1990). The research data were analyzed descriptively and used Pearson correlation with the assistance of SPSS. The descriptive test revealed that self-esteem is quite good (67\%), responsibility for learning is relatively good (54.6\%), and students' group learning commitment is quite good $(65.9 \%)$. Whereas, the Pearson test indicated that there is a positive and significant relationship between selfesteem and learning responsibilities $(0.468)$ and the students' group learning commitment (0.282). This study emphasizes that lecturers and peers need to support, maintain, and develop positive self-esteem through supportive feedback to encourage students' learning behavior, such as being responsible and committed to group learning in completing various learning tasks.
\end{abstract}

Keywords: Self-Esteem; Learning Responsibilities; Group Learning Commitments; Physical Education Students.

\section{INTRODUCTION}

The learning process is an extended practice that emphasizes the active role of students. It involves a central and multi-directional concept known as interaction (Kansanen, 2006). Furthermore, the interaction between lecturers and students is a mutual consensus that encourages confrontation and negotiation through the use of various approaches, methods, and strategies as an effort to confirm ideas. According to Liang, Huang, \& Tsai (2012), these strategies usually results in an orderly development of shared consensus. Lecturers start by offering materials, methods, and strategies to students during meetings in order to explore their intended learning goals (Faulconer, 2017; Blegur, Wasak, \& Pabala, 2018) and also to recognize their potentials (Blegur, Mae, \& Souisa, 2018). The learning strategies and methods contain specific materials used to train students' social-emotional maturity and psychomotor sensitivity.

Students exhibit various characteristics during learning, and these are in accordance with the lecturer's study plan. These constraints arise from either external or internal factors such as learning responsibility and group commitment. Kusumadewi, Sedanayasa, \& Antari (2014) 
started that one of the factors that cause problems in learning is lack of responsibility. Furthermore, every student needs to be effective during lectures to contribute to the achievement of goals and long-term careers (Yasmin, Santoso, \& Utaya, 2016). Other behaviors also contributes to the instability of the learning processes, such as lack of mutual decisions, entering the class late, carrying out researches without consulting scientific journals, or being unprepared during presentations. These behaviors cause lack of personal trust, responsibility, disharmony, and unconducive learning environment, poor academic performance, and feelings of regret/disappointment towards self (Wasak, Manggoa, \& Blegur, 2016). However, these problems are overcome by a committed work culture. Commitment to work prevents students from getting bored (Leiter \& Maslach, 1988) reduces the effects of failure and increases loyalty (Mattila, 2004).

Students do not appreciate personalized efforts and abilities. Rather, they tend to depend on fellow peers when carrying out tasks, and this causes these individuals to be stuck with the waiting behavior. In addition, they exhibit a high rate of waiting and dependent behavior, which often leads to passive and receptive learning activities. Such conditions have a direct impact on the students' performance and learning outcomes because they perceive each other as destructive individuals. Self-esteem is conceptualized as the evaluation of a person and is expressed in the belief to be competent, successful, and valuable (Kamila \& Mukhlis, 2013; Srivastava \& Joshi, 2014). Peer labeling, passive, and receptive behaviors also contribute to the formation of selfesteem. According to Kamila \& Mukhlis (2013), a wellbehaved individual tends to develop positive self-esteem while, on the contrary, a person with low self-esteem shows behaviors such as difficulties in paying attention, breaking academic and social rules in educational institutions (Kamila \& Mukhlis, 2013). This poor self-esteem tends to shape bad work ethos, social and academic difficulties in the future (Crocker \& Luhtanen, 2003; Trzesniewski et al., 2006).

Furthermore, to exhibit the best in students during learning activities, lecturers need to encourage certain characters, namely self-appreciation, responsibility, and commitment. They also need to be able to design learning activities with the aim of training students to become independent when carrying out their responsibilities (Fatihah, 2016). Wentzel (1991) stated that responsibility facilitates performance and learning outcomes. In addition, lectures need to provide technical guidelines and urge students to be highly committed to learning and always focus on carrying out their tasks to the maximum (Prasetyo, Mukhadis, \& Sutijono, 2013). Additionally, commitment increases students' opportunities in achieving work targets and academic performance (Haftkhavani, Faghiharam, \& Araghieh, 2012). Teachers need to develop students' selfesteem during interactions in a class by offering supportive instructions because it is shown to suppress academic procrastination (Khotimah, Radjah, \& Handarini, 2016). It has an impact on academic performance (Rosli et al., 2012; Arshad, Zaidi, \& Mahmood, 2015) and is stated to contribute to learning achievement (Aryana, 2010; Rahmani, 2011; Adiputra, 2015; Doodman, Zadeh, \& Changizi, 2017).

The environment's subjectivity in defining a person also influences their self-esteem. Siqueira, Oliveira, \& de Souza (2017) stated that when the environment views a person as being bad, it is generally believed that that individual has an irritating personality. This is one of the causes of students' low self-esteem and it is easily showed in their behavior (Kezemi et al., 2018). Self-esteem is defined as being able to help individuals behave ethically and responsibly in an organization. According to Potgieter (2012), a person's workability is also influenced by self-esteem, as confident people tend to put in their best while working. This promotes positivity, aids in the relationship between superiors and subordinates, and also fosters work ethics (Suar, Gochhayat, $\&$ Suar, 2016). However, only a few researches investigate the relationship between self-esteem and learning responsibilities, subsequently, confident students are responsible. In addition, self-esteem is also assessed as an important attribute that causes students to be committed during group discussions. Therefore, this study aims to examine the association of self-esteem with students' learning responsibilities and group learning commitments.

\section{METHOD}

\section{A. Procedure}

This study employed a quantitative approach in order to examine the positivity and significance of self-esteem in association with learning responsibilities and students' group commitment. Firstly, the research instrument was copied based on the specified number of samples. Secondly, lecturers coordinating other subjects and students of such departments were permitted to participate in this study. Thirdly, guidance on how to fill out the questionnaires was provided. The last procedure was conducting descriptive analysis and Pearson correlation to examine the relationship between self-esteem and responsibility for learning and commitment to students' learning groups.

\section{B. Participant}

The research samples consisted of students, and they filled the questionnaire. Furthermore, additional information and clarified unclear information were provided with the samples. This procedure applied to each stratification class consisting of $\mathrm{A}, \mathrm{B}, \mathrm{C}$, and $\mathrm{D}$ with a proportional random sampling technique used to collect data from 88 students. Class A consists of 24 students, class B was made up of 18 people, while class $\mathrm{C}$ and $\mathrm{D}$ involve 18 and 28 individuals, respectively $(\mathrm{M}=22.5341, \mathrm{SD}=2.91626)$. Samples are students in the sixth-semester of Physical Education, Health and Recreation Study Program, Faculty of Teacher Training and Education, Universitas Kristen Artha Wacana, academic year 2018/2019.

\section{Instrument}

Data from the students' self-esteem was collected by using the State Self-Esteem Scale (SSES) created by T. F. Heatherton and J. Polivy in 1991. The State Self-Esteem 
Scale includes 20 closed statements constructed from three indicators: 1) Performance self-esteem $(1,4,5,9,14,18,19)$, 2) Social self-esteem $(2,8,10,13,15,17,20)$, and 3$)$ Appearance self-esteem $(3,6,7,11,12,16)$. Furthermore, the data for students' learning responsibility was collected by employing the Personal Responsibility Questionnaire (PRQ) developed by Amanda Mergler in 2007, and it consists of 30 closed statements on five-point scales. This questionnaire is made up of two main indicators; Locus of control which involves 18 items $(2,4,5,6,7,9,11,12,15$, $16,18,19,21,23,24,26,28,30)$ and emotional intelligence made up of 12 items $(1,3,8,10,13,14,17,20,22,25,27$, 29). Additionally, students' learning commitment data was modified by the Organization Commitment Scale (OCS), which was developed by Natalie J. Allen and John P. Meyer in 1990. Generally, OCS involves a total of 24 items, including: 1) Affective commitment (1, 2, 3, 4, 5, 6, 7, 8), 2) Continuance commitment $(9,10,11,12,13,14,15,16)$, and 3 ) Normative commitment (17, 18, 19, 20, 21, 22, 23, 24).

\section{Data Analysis}

The research data/quantitative values were partially analyzed descriptively to profile students' self-esteem, responsibility, and commitment before examining its association values, as shown in table 1. After profiling the research variables, correlation analysis using Pearson product-moment was conducted, using Windows SPSS 20. When the alpha value is less than $0.05 \quad(<0.05)$, the hypothesis is accepted, this means that a positive and significant relationship exists among self-esteem, students' learning responsibility and group learning commitment.

TABLE I

INTERPRETATIONS OF SELF-ESTEEM, LEARNING RESPONSIBILITY, AND GROUP LEARNING COMMITMENT

\begin{tabular}{cccc}
\hline Self-esteem & $\begin{array}{c}\text { Learning } \\
\text { responsibility }\end{array}$ & $\begin{array}{c}\text { Group learning } \\
\text { commitment }\end{array}$ & Interpretation \\
\hline $85-100$ & $127-150$ & $100.9-120$ & Excellent \\
$69-84$ & $103-126$ & $81.7-100.8$ & Good \\
$53-68$ & $79-102$ & $62.5-81,6$ & Fair \\
$37-52$ & $55-78$ & $43.3-62.4$ & Poor \\
$20-36$ & $30-54$ & $24-43.2$ & Very poor \\
\hline
\end{tabular}

\section{RESULT AND DISCUSSION}

A descriptive analysis was conducted to interpret the variables of self-esteem, learning responsibility, and group commitment. It was divided into 5 categories, namely, excellent, good, fair, poor, and very poor based on the norms in table 1. The description of self-esteem, learning responsibility, and students' group commitment variables are also shown in table 2 . The results from this test showed that the variables of self-esteem $(67 \%)$ and learning responsibility $(54.6 \%)$ are rated good while the group learning commitment $(65.9 \%)$ is rated fair.
TABLE II

SELF ESTEEM DESCRIPTION, LEARNING RESPONSIBILITY, AND STUDENTS' GROUP LEARNING COMMITMENT

\begin{tabular}{ccccccc}
\hline \multirow{2}{*}{ Interpretation } & \multicolumn{2}{c}{ Self-esteem } & \multicolumn{2}{c}{$\begin{array}{c}\text { Learning } \\
\text { responsibility }\end{array}$} & $\begin{array}{c}\text { Group learning } \\
\text { commitment }\end{array}$ \\
\cline { 2 - 7 } & $\mathrm{F}$ & $\%$ & $\mathrm{~F}$ & $\%$ & $\mathrm{~F}$ & $\%$ \\
\hline Excellent & 7 & 8 & 3 & 3.4 & 0 & 0 \\
Good & 59 & 67 & 48 & 54.6 & 29 & 33 \\
Fair & 20 & 22.7 & 37 & 42 & 58 & 65.9 \\
Poor & 2 & 2.3 & 0 & 0 & 1 & 1.1 \\
Very poor & 0 & 0 & 0 & 0 & 0 & 0 \\
Mean & 73.3068 & 105.1818 & 78.2955 \\
Std. Dev. & 7.98470 & 9.94646 & 6.33029 \\
\hline
\end{tabular}

Pearson test was conducted to show the close relationship between the three research variables, the association between the variables of self-esteem, learning responsibility, and group learning commitment. The results of this test were marked by significance and r-table values. However, when the significance value is less than 0.05 , it simply means that there is a positive and significant relationship among the variables. Table 3 shows that there is positive and significant association between students' self-esteem and learning responsibilities. This means that a significance value of less than 0.01 (0.000), with an r-value of 0.468 , was obtained. A similar thing is also evident in statistical testing of price variables and group learning commitments. The significance value is smaller than 0.05 (0.008), with a calculated r-value of 0.282 . This statistical test is recommended for lecturers to maintain the stability of students' self-esteem in a positive trend in order to support the learning culture and commitment towards it to ensure that the process becomes more active, constructive, productive, and successful.

TABLE III

PEARSON TEST OF SELF-ESTEEM, LEARNING RESPONSIBILITY, AND GROUP LEARNING COMMITMENT

\begin{tabular}{lccc}
\hline \multicolumn{1}{c}{ Variable } & N & Sig. & r-value \\
\hline $\begin{array}{l}\text { Self-esteem > Learning } \\
\text { responsibility }\end{array}$ & 88 & 0.000 & $0.468^{* *}$ \\
$\begin{array}{l}\text { Self-esteem > Group learning } \\
\text { > }\end{array}$ & 88 & 0.008 & $0.282 * *$
\end{tabular}
commitments

**. Correlation is significant at the 0.01 level (2-tailed).

\section{A. Self Confidence Accelerates Problem Solving}

Each student has a certain level of ability, which needs to be optimized in order to improve their capability. Conversely, some students are not able to improve their abilities. To achieve this improvement, students need to be confident in their ability to think, socialize, play football, etc. In addition, their ability during academic activities is closely related to learning outcomes. Therefore, students with good learning outcomes ideally have good and even representative abilities. For example, the researches conducted by Blegur, Manu, \& Souisa (2018) stated that students that are welldisciplined tend to shape their self-esteem and academic performance. Therefore, disciplined students develop their 
self-esteem and academic performance. Good academic performance leads to more stable self-esteem.

Self-esteem significantly correlates with exploration (Valdez, 2015), thereby it encourages students to discover and identify obstacles encountered during learning. Students encounter various unresolved problems during the learning process. The negligence of the lecturers leads to lack of confidence in students' ability to discover solutions to problems, thereby, creating a barrier their self-actualization. Tlonaen \& Blegur (2017) stated that lack of self-confidence slowly causes students to perceive learning as being difficult. Some students are initially confident in participating in any activity, and are influenced by the poor performance of the lecturers. According to Blegur (2017), students become confident after successfully passing the learning task by employing the individual presentation method. It aids students to obtain solutions and to overcome the problem of anxiety during presentations and helps them make decisions, even in critical situations. The above phenomenon of personal responsibility and a high level of self-confidence shows that students are responsible for their decisions.

\section{B. Academic Success as a Form of Future Career Responsibility}

The ability to achieve success is dependent on students' and makes them responsible to their parents, lecturers, and colleagues. This is important for them to achieve future goals that manifest in both intra and extra-curricular activities. Students enroll into the university with a preferred course of study, which is an accumulative vision that becomes their future career. For instance, an individual that desires to become a Physical Education teacher gets enrolled in the Physical Education Department while economists are enlisted in the Economics Department. Therefore, students need to pass through the dynamics of learning in schools or external environment, to achieve their future goals. Additionally, they need to more active in learning, with more efforts to discover solutions, and to overcome challenges.

Lecturers and parents contribute immensely to students willingness to succeed. A students' self-worth is stimulated when they are successful, and this incites the individuals to become responsible. Self-esteem is positively related to an individual's personal and social responsibility. Furthermore, people that are highly confident have a sense of empowerment that enhances their personal and social behaviors (Ağbuğa, 2014), such individuals optimally carry out their duties and responsibilities (Prasetyo, Mukhadis, \& Sutijono, 2013), personal development and create supportive work environment (Crocker \& Luhtanen, 2003). The longterm career of students starts with exhibiting responsible behaviors (Yasmin, Santoso, \& Utaya, 2016) because this helps in successful academic performance (Wentzel, 1991). According to Komba (2017) to improve student learning outcomes, there needs to be a formulated and effective attitude towards being responsible to identify areas of work that need to be prioritized within the required time. Students need to start with consistency in completing tasks under the learning plan provided by the lecturers.

\section{Admitting Mistakes is not due to Worry About the Impression of Others}

Self-esteem plays an important role in shaping the thought and aspirations of an individual's life and professional career (Shukla \& Kateeth, 2016). Therefore confident people think of long-term visions, unlike those with temporal perceptions in accordance with the actions and impression of others. Conversely, it is also due to their ability to act in accordance with the primary goal, by admitting mistakes. Zuriah (2007) stated that honesty is an individual's attitude/behavior of not lying and cheating. The definition emphasizes on the fact that the act of being honest or accepting mistake is carried out to maintain subjectivity (Utami et al., 2017; Devi \& Jyotsana, 2018). Individuals with low self-esteem exhibit deviant behavior, such as cheating, disloyalty (Błachnio \& Weremko, 2011), and tend to be aggressive (Donnellan et al., 2005; Lee, 2014).

Students are often trapped in other people's perceptions and when this occurs, they tend to live a manipulative life. However, these changes need to be appropriately referred to an individual's main goal to avoid manipulating them into acting like others, which does not help in personal development. Admitting mistakes is an effort to renew a person, some mistakes are intentionally or unintentionally carried out and needs accountability. This form of responsibility is also referred to as a type of admission that leads to self-improvement. Therefore, when a student makes a mistake and admits it without necessary amendments, then that individual is either under pressure or afraid of people. According to Kanning \& Hill (2012), admitting mistakes is a form of evaluating a person's self-esteem, for example, some students dare to admit cheating (Rusdini, Rachman, \& Handoyo, 2016). Therefore, two principles need to be explicitly emphasized in accordance with the admission of mistakes as a process of evaluating self-esteem. The first is associated with their ability to admit to unimportant actions, and acceptance due to the awareness of self-improvement. This means that, admitting mistakes is an honorable and responsible attitude and behavior that need to be exhibited by students without external pressure.

\section{Appreciation from Peers Strengthens Group Learning Commitments}

Students try to offer their best abilities for selfdevelopment and the achievement of goals when learning in groups. For example, the strengths of student " $A$ " are used to complement the weaknesses of "B." This is because the essence of studying in groups is for the empowerment and self-development of every student. Each member needs to appreciate the strengths of others to elevate the social status of the group, due to its necessity in developing their selfesteem. This enables students to show appreciation, which is a form of peer emotional support that encourages selfimprovement. The nuance of appreciation also applies to persons that have unsuccessfully tried to build their 
confidence, and ensures that students remain involved in group discussion in order to complete their assignments (Blegur, Wasak, \& Rosari, 2019). Furthermore, students' need to start appreciation with simple statements such as, "Wow! Your work helped our group", "Thank you for helping me complete the group assignment," "Your explanation and assistance helped me," etc. Respect for others is quite remarkable and reduces various forms of discrimination (Jackson \& Jackson, 2019), enhances job satisfaction (Mocheche, Bosire, \& Raburu, 2017), and organizational commitment (Omole et al., 2019). It also affects self-esteem and employee performance thereby creating an associative relationship (Indrayanto, 2012).

Positive and constructive self-esteem is able to facilitate individuals to conduct psychological adjustments, which, in the end, supports social adaptation, even some people obtain a life-time satisfaction from the influence of self-esteem (Reina, Oliva, \& Parra, 2010). In addition, self-esteem also mediates the prevention of certain risk behaviors, such as helping individuals to overcome avoidance attitudes (Srisayekti, Setiady, \& Sanitioso, 2015). Various social inequalities tend to occur due to low self-esteem among group members. Furthermore, the vulnerability is wide open due to peoples' different backgrounds racial, religious, and cultural differences, diversities in abilities, status, etc. Selfesteem is not always based on "superior" behaviors, however it also depends on "stagnant" attitudes due to people's different ways of life. Conversely, it needs to be ensured that the students contributed their best. i.e. student "A" was not able to properly complete the observation paper, however data was correctly obtained. The cause of the condition above is the limitation in processing and analyzing the data. According to Sadoughi \& Ebrahimi (2014), when a person develops self-esteem, they remain committed because group learning is not a field of competition, rather it is that of complementarity.

\section{E. Self-Esteem Includes Loyalty at Work}

Students with self-esteem are highly committed to and focus on set goals (Heatherton \& Ambady, 1993), including building relationships (Rill et al., 2009). They are proud of their achievements and careless on what other people think or say about such individuals (Maheswari \& Maheswari, 2016). The constellation of the learning group implies various responses from members. Some are supportive, while some are destructive. Such responses either causes the students to advance or to fail. Therefore, to overcome such responses, students' self-esteem needs to be facilitated as a "fortress" so as not to be easily trapped by various destructive responses that weakenings an individuals' commitment towards work. Individuals work faithfully because of various factors, such as the appropriateness of the job conducted (Altindag \& Siller, 2014), and this loyalty is admitted and valued (Murali, Poddar, \& Seema, 2017). When an individual perceives a job as fun and positive, surely that person is continually faithful to the work. How is it possible for a person to work faithfully when that individual does not recognize personal existence such as skills, enthusiasm, creativity, and knowledge?. The studies conducted by Park et al (2018) discovered that self-esteem is positively related to efficacy and choice of career, however, it is negatively related to anxiety. Therefore, students with self-esteem are able to determine future careers by being loyal to the work, they are assigned.

Students with high self-esteem believe in its abilities that are capable of making such persons' successful (Kamila \& Mukhlis, 2013; Srivastava \& Joshi, 2014). This makes such students "love" their personality, whether they succeed or fail (Maheswari \& Maheswari, 2016). However, high selfesteem is less responsive to perceptions of organizational uncertainty (Hui \& Lee, 2000). A lot of students respond to failure or uncertainty such situations often diverts students' attention from their learning goals. Subsequently, failure and uncertainty are part of the learning process for students to make improvements and become more productive. Selfesteem, in both positive and negative conditions, provides students with the energy to be more active and loyal to learn. For example, student " $\mathrm{A}$ " is confident on its abilities to complete the given assignments. The student is committed to discovering solutions and answers to the tasks being carried out. Faithful is defined as the students' attempt to discover new ideas/concepts. On the contrary, student "B" has less teaching ability, however this individual believes to be better and explores the instrument and rubric for teaching skills assessment, which is demonstrated after class hours. The two examples confirm that self-esteem encourages/projects students as individuals that are willing to strive and are also oriented towards self-improvement.

\section{F. Self-Awareness Stimulates Students to Develop their Careers}

Nandhi (2017) stated that high self-esteem helps individuals to succeed in any given career. The future career development of students actually starts from the family, elementary and high schools, and then the university. At the university level, students only need to strengthen a number of skills, abilities, relationships, and collaboration, as well as consistency in the main goals of their careers. The development of self-esteem is formed at an early age in student life and has an impact on the foundation of personality and the development of self-components during adolescence (Tripathi \& Pandey, 2018). Neglect of selfesteem is detrimental to students, they query their abilities and have unrealistic expectations concerning their personalities. In addition, such individuals are easily broken down in various ways, particularly in academics. According to Şentuna (2015), they are also easily influenced by the opinions of others and often carry out destructive selfcriticism, which ultimately creates an unhealthy work environment and such individuals experiences social and academic difficulties in the future (Crocker \& Luhtanen, 2003; Trzesniewski et al., 2006).

It is not possible for students to build significant career development without self-awareness. They need to be aware of the purpose of being in a study group, participating in the learning activities and also getting involved in higher 
education. Self-awareness is a manifestation of self-esteem, therefore to arouse it students' self-esteem needs to be examined first. Experimental results from Level (2015) states that increase in students' self-esteem also causes an increases in self-awareness. Self-awareness guides students in being selective during learning and group activities that are relevant to its needs, progress and self-improvement. Students are certainly aware that there are career goals they need to achieve, both in study groups and long-term career investments. For example, student "A" properly conducts a research because the individual needs to develop thinking and writing skills to support the student's professional career as a teacher. Such actions have manifested a future career (i.e the desire to be a professional teacher). Therefore, student learning activities become more productive and constructive, because the individual desires to be valuable to self and others. This condition confirms that self-esteem is also related to critical thinking, job satisfaction, personal and organizational improvement (Sadoughi \& Ebrahimi, 2014), self-efficacy and life satisfaction (Reina, Oliva, \& Parra, 2010).

\section{CONCLUSIONS}

Self-esteem plays an important role in students' personal development because it is highly regarded in learning responsibilities and group learning commitments. Lecturers need to maintain supportive classes for students to perceive each other as being equals. This effort is an aspect of practicing students' self-esteem as well as of determining the continuity of a conducive, participatory and active learning process, including being responsible during academic activities and commitment towards learning in groups. Students with high self-esteem are able to create a good self profile in various learning activities, they offer a variety of abilities and skills in supporting a dynamic training atmosphere. With various tasks carried out, the students do not perceive the task as boring or tiring, rather it is perceived as a process that supports both personal and future career developments.

Group learning commitments is often an obstacle in any class with high level of disparity, however, this difference is circumvented by a culture of positive self-esteem of lecturers and peers. Furthermore, they are supported by students that contributed through self-confidence, academic success orientation, willingness/courage to admit mistakes, mutual respect for peers' strengths, faithfulness in learning, and having awareness of each task conducted. Therefore, lecturers and students need to maintain and develop positive self-esteem and supportive feedback to ensure that students become responsible individuals.

\section{ACKNOWLEDGMENTS}

The authors are grateful to June A. Jacob, S.Pd., M.A., Dean of the Teacher Training and Education Faculty and the main sponsor of the activities conducted during this study through the Faculty Top Research Scheme with the contract number: 35/LP-UKAW/P.10/VII.2019.

\section{REFERENCES}

Adiputra, S. (2015). Keterkaitan Self Efficacy dan Self Esteem terhadap Prestasi Belajar Mahasiswa. Jurnal Fokus Konseling, 1(2), 151-161. https://doi.org/10.26638/jfk.101.2099

Ağbuğa, B. (2014). Relationship between Self-Esteem and Personal and Social Responsibility in Young Boxers. Pamukkale Journal of Sport Sciences, 5(2), 48-59. Retrieved from https://dergipark.org.tr/en/pub/psbd/issue/20584/21 $\underline{9360}$

Allen, N. J., \& Meyer, J. P. (1990). The Measurement and Antecedents of Affective, Continuance and Normative Commitment to the Organization. Journal of Occupational Psychology, 63, 1-18. https://doi.org/10.1111/j.2044-8325.1990.tb00506.x

Altindag, E., \& Siller, F. (2014). Effects of Flexible Working Method on Employee Performance: An Empirical Study in Turkey. Business and Economics Journal, 5(3), 1-7. DOI: 10.4172/2151$\underline{6219.1000104}$

Arshad, M., Zaidi, S. M. I. H., \& Mahmood, K. (2015). SelfEsteem \& Academic Performance among University Students. Journal of Educational Practice, 6(1), 156-162. Retrieved from https://iiste.org/Journals/index.php/JEP/article/view $\underline{122058}$

Aryana, M. (2010). Relationship between Self-Esteem and Academic Achievement amongst Pre-University Students. Journal of Applied Sciences, 10, 2474 2477. DOI:10.3923/jas.2010.2474.2477

Błachnio, A., \& Weremko, M. (2011). Academic Cheating is Contagious: The Influence of the Presence of others on Honesty. A Study Report. International Journal of Applied Psychology, 1(1), 14-19. DOI: 10.5923/j.ijap.20110101.02

Blegur, J. (2017). Eksplorasi Motivasi Belajar Mahasiswa dengan Mediasi Metode Mengajar. Seminar Hasil Penelitian Pendidikan. Pemberdayaan Hasil Penelitian melalui Seminar: Mendorong Peningkatan Penulisan Artikel dan Publikasi (hal. 140-150), Jakarta, Universitas Negeri Jakarta.

Blegur, J., Mae, R. M., \& Souisa, M. (2018). I Feel Anxious when Communicating: Questioning Students' Learning Readiness. International Conference on Technology, Education, and Social Science (pp. 75-85), Surakarta, Universitas Slamet Riyadi. Retrieved from http://ejurnal.unisri.ac.id/index.php/proictss/article/ view/2142

Blegur, J., Wasak, M. R. P., \& Pabala, P. (2018). Students' Academic Self-Concept: A Founding Strategy in Learning Process. International Journal of Indian Psychology, 6(4), 44-54. Retrieved from https://ijip.in/article-details/?dip=18-01-046$\underline{20180604}$ 
Blegur, J., Wasak, M. R. P., \& Rosari, R. (2019). Student's Self-Confidence Restoration with Peer Mentoring Strategy. European Scientific Journal, 15(1), 129148 . http://dx.doi.org/10.19044/esj.2019.v15n19p129

Crocker, J., \& Luhtanen, R. K. (2003). Level of Self-Esteem and Contingencies of Self-Worth: Unique Effects on Academic, Social, and Financial Problems in College Students. Personality and Social Psychology Bulletin, 29(6), 701-712. https://doi.org/10.1177/0146167203029006003

Devi, S., \& Jyotsana. (2018). Forgiveness, Self Esteem and Subjective Well-Being among Females Across Age. Journal of Humanities and Social Science, 23(1), 48-77.

Donnellan, M. B., Trzesniewski, K. H., Robins, R. W., Moffitt, T. E., \& Caspi, A. (2015). Low SelfEsteem is Related to Aggression, Antisocial Behavior, and Delinquency. Psychological Science, 16(4), 328-335. https://doi.org/10.1111/j.09567976.2005.01535.x

Doodman, P., Zadeh, M. A., \& Changizi, B. (2017). Study the Relationship between Self-Esteem and Academic Achievement among High School Students in Lamerd City. International Journal of Scientific Study, 5(3), 221-226. DOI: 10.17354/ijssJuneI/2017/032

Fatihah, M. A. (2016). Hubungan antara Kemandirian Belajar dengan Prestasi Belajar PAI Siswa Kelas III SDN Panularan Surakarta. Al-Takawi, 1(2), 197208. DOI: $10.22515 /$ attarbawi.v1i2.200

Faulconer, E. K. (2017). Increasing Student Interactions with Learning Objectives. Journal of College Science Teaching, 46(5), 32-38. Retrieved from https://commons.erau.edu/publication/462

Haftkhavani, Z. G., Faghiharam, B., Araghieh, A. (2012). Organizational Commitment and Academic Performance (Case Study: Students at Secondary Schools for Girls). Procedia-Social and Behavioral Sciences, 69(24), 1529-1538. https://doi.org/10.1016/j.sbspro.2012.12.095

Hearherton, T. F., \& Ambady, N. (1993). Self-Esteem, Selfprediction, and Living up to Commitments. In Baumeister, R. F. (Ed.), Self-esteem: The puzzle of low self-regard (pp. 131-145). New York: Plenum Press. https://doi.org/10.1007/978-1-4684-8956-9 7

Heatherton, T. F., \& Polivy, J. (1991). Development and Validation of a Scale for Measuring State SelfEsteem. Journal of Personality and Social Psychology, 60, 895-910. http://dx.doi.org/10.1037/0022-3514.60.6.895

Hui, C., \& Lee, C. (2000). Moderating Effects of Organization Based Self-Esteem on Organizational Uncertainty: Employee Response Relationships. Journal of Management, 26(2), 215-232. https://doi.org/10.1177/014920630002600203

Indrayanto, A. (2012). Pengaruh Organization-Based SelfEsteem terhadap Komitmen Organisasional dan
Dampaknya Pada Kinerja Pegawai. Jurnal Ekonomi Moderniasi, 8(1), 68-77. Retrieved from http://ejournal.unikama.ac.id/index.php/JEKO/articl e/view/207

Jackson, S., \& Jackson, L. T. B. (2019). Self-Esteem: Its Mediating Effects on the Relationship between Discrimination at Work and Employee Organisation Commitment and Turn-Over Intention. Journal of Psychology in Africa, 29(1), 13-21. https://doi.org/10.1080/14330237.2019.1568065

Kamila, I. I., \& Mukhlis. (2013). Perbedaan Harga Diri (Self esteem) Remaja ditinjau dari Keberadaan Ayah. Jurnal Psikologi, 9(2), 100-112. http://dx.doi.org/10.24014/jp.v9i2.172

Kanning, U. P., \& Hill, A. (2012). Organization-Based SelfEsteem Scale-Adaptation in an International Context. Journal of Business and Media Psychology, 3(1), 13-21.

Kansanen, P. (2006). Teaching as Teaching-StudyingLearning Interaction. Scandinavian Journal of Educational Research, 43(1), 81-89. DOI: 10.1080/0031383990430105

Kazemi, Y., Nikmanesh, Z., Khosravi, M., \& Hassanzadeh, Z. (2018). The Relationship of Self-Esteem and Attributional Styles with Self-Handicapping in Primary Schools. Int J School Health, 5(1), 1-6. doi:10.5812/intjsh. 13162.

Khotimah, R. H., Radjah, C. L., \& Handarini, D. M. (2016) Hubungan antara Konsep Diri Akademik, Efikasi Diri Akademik, Harga Diri Akademik Pada Siswa SMP Negeri di Kota Malang. Jurnal Kajian Bimbingan dan Konseling, 1(2), 60-67. http://dx.doi.org/10.17977/um001v1i22016p060

Komba, A. A. (2017). Educational Accountability relationships and Students' Learning Outcomes in Tanzania's Public Schools. SAGEOpen, 7(3), 1-12. https://doi.org/10.1177/2158244017725795

Kusumadewi, K. R., Sedanayasa, G., \& Antari, N. N. M. (2014). Efektivitas Konseling Gestalt Dengan teknik "Saya Bertanggung Jawab Atas...." untuk meningkatkan Tanggung Jawab Akademik Siswa. Jurnal Online Jurusan Bimbingan dan Konseling, 2(1), 1-12. Retrieved from https://ejournal.undiksha.ac.id/index.php/JJBK/artic $\underline{\text { le/view/3645 }}$

Lee, E. J. (2014). The Relationship between Unstable SelfEsteem and Aggression: Differences in Reactive and Proactive Aggression. Journal of Early Adolescence, $\quad 34(8), \quad$ 1075-1093. https://doi.org/10.1177/0272431613518973

Leiter, M. P., \& Maslach, C. (1988). The Impact of Interpersonal Environment on Burnout and Organizational Commitment. Journal of Organizational Behavior, 9(4), 297-308. https://doi.org/10.1002/job.4030090402

Level, R. (2015). Enhancing Self Esteem and Building Self Awareness of a Selected Group of Grade Five Students in an Inner-City Primary School in 
Jamaica. The Bridge: Journal of Educational Research-Informed Practice, 2(2), 28-52.

Liang, T-H., Huang, Y-M., \& Tsai, C-C. (2012). An Investigation of Teaching and Learning Interaction Factors for the use of the Interactive Whiteboard Technology. Educational Technology \& Society, 15(4), 356-367. Retrieved from https://www.jets.net/ETS/issues850a.html?id=57

Maheswari, R., \& Maheswari, K. (2016). A Study on SelfEsteem among the College Students. Journal of Humanities and Social Science, 21(10), 8-10.

Mattila, A. S. (2004). The Impact of Service Failures on Customer Loyalty: The moderating role of Affective Commitment. International Journal of Service Industry Management, 15(2), 134-149, https://doi.org/10.1108/09564230410532475

Mergler, A. (2007). Personal Responsibility: The Creation, Implementation and Evaluation of a School-Based Program. (unpublished dissertation). Faculty of Education, Queensland University of Technology, Kelvin Grove Campus, Queensland.

Mocheche, E. K., Bosire, J., \& Raburu, P. (2017). Influence of Self-Esteem on Job Satisfaction of Secondary School Teachers in Kenya. International Journal of Advanced and Multidisciplinary Social Science, 3(2), 29-39. Retrieved from http://article.sapub.org/10.5923.j.jamss.20170302.0 1.html

Murali, S., Poddar, A., \& Seema, A. (2017). Employee Loyalty, Organizational Performance \& Performance Valuation-A Critical Survey. Journal of Business and Management, 19(8), 62-74.

Nandhi, D. (2017). Siblings' Birth order Interaction and Self-Esteem Development: Forgotten Social setting for e-Health Delivery in Tanzania? International Journal of Education and Research, 5(1), 51-68.

Omole, O. E., Ajayi, J. O., Olagundoye, H. F., \& Olaide, R. Y. (2019). The Influence of Self-Esteem and Job Satisfaction on the Commitment of Secondary School Teachers in Owo Local Government Area, Nigeria. The International Journal of Humanities \& Social Studies, 7(6), 47-51. Retrieved from http://www.internationaljournalcorner.com/index.p hp/theijhss/article/view/147547/0

Park, I-J., Kim, M., Kwon, S., \& Lee, H-G. (2018). The relationships of Self-Esteem, Future Time Perspective, Positive Affect, Social Support, and Career Decision: A Longitudinal Multilevel Study. Frontiers in Psychology, 9(514), 1-14. https://doi.org/10.3389/fpsyg.2018.00514

Potgieter, I. (2012). The relationship between the SelfEsteem and Employability Attributes of Postgraduate Business Management Students. SA Journal of Human Resource Management/SA Tydskrif vir Menslikehulpbronbestuur, 10(2), 1-15. http://dx.doi.org/10.4102/sajhrm.v10i2.419

Prasetyo, M. R., Mukhadis, M., \& Sutijono. (2013). Komitmen Guru dalam mengelola Pembelajaran
Pada Jurusan Otomotif SMK. Teknologi dan Kejuruan, 36(2), 173186.http://dx.doi.org/10.17977/tk.v36i2.4080

Rahmani, P. (2011). The relationship between Self-Esteem, Achievement Goals and Academic Achievement among the Primary School Students. ProcediaSocial and Behavioral Sciences, 29, 803-808. https://doi.org/10.1016/j.sbspro.2011.11.308

Reina, M. d. C., Oliva, A., \& Parra, Á. (2010). Percepciones de Autoevaluación: Autoestima, Autoeficacia y Satisfacción Vital en la Adolescencia. Psychology, Society, \& Education, 2(1), 55-69. http://dx.doi.org/10.25115/psye.v2i1.435

Rill, L., Baiocchi, E., Hopper, M., Denker, K., \& Olson, L. N. (2009). Exploration of the relationship between Self-Esteem, Commitment, and Verbal Aggressiveness in Romantic Dating Relationships. Communication Reports, 22(2), 102-113. https://doi.org/10.1080/08934210903061587

Rosli, Y., Othman, H., Ishak, I., Lubis, S. H., Saat, N. Z. M., \& Omar, B. (2012). Self-Esteem and Academic Performance Relationship amongst the Second Year Undergraduate Students of Universiti Kebangsaan Malaysia, Kuala Lumpur Campus. Procedia-Social and Behavioral Sciences, 60(17), 582-589. https://doi.org/10.1016/j.sbspro.2012.09.426

Rusdini, S. E., Rachman, M., \& Handoyo, E. (2016). Pelaksanaan internalisasi Kejujuran dalam Pendidikan Antikorupsi di SMP Keluarga Kudus. Journal of Educational Studies, 5(1), 24-32. Retrieved fromhttps://journal.unnes.ac.id/sju/index.php/jess/ar ticle/view/13091

Sadoughi, F., \& Ebrahimi, K. (2014). Self Esteem and Organizational Commitment among Health Information Management Staff in Tertiary Care Hospitals in Tehran. Global Journal of Health Science, $\quad 7(2), \quad 328-334$ http://dx.doi.org/10.5539/gjhs.v7n2p328

Şentuna, M. (2015). Investigation of Job Satisfaction, Organizational Commitment and Self-Esteem of Physical Education Teachers according to the Gender. International Online Journal of Educational Sciences, 7(2), 93-101. DOI: 10.15345/iojes.2015.02.005

Shukla, D., \&Katepeth, A. (2016). Mediating role Examination of Self-Esteem on Career Decisiveness and Career Commitment: An Empirical Investigation on Thai Young Adults. Journal of Psychological \& Educational Research, 24(1), 115-133.

Siqueira, N. F., Oliveira, F. L. B. B., \& de Souza, E. A. P. (2017). Impaired Responsibility Dimension of SelfEsteem of Brazilian Adolescents with Epilepsy. Epilepsy \& Behavior, 73, 1-5. https://doi.org/10.1016/j.yebeh.2017.05.009 
Srisayekti, W., Setiady, D. A., \& Sanitioso, R. B. (2015). Harga Diri (Self-Esteem) Terancam dan Perilaku Menghindar. Jurnal Psikologi, 42(2), 141-156.DOI: $\underline{10.22146 / j p s i .7169}$

Srivastava, R., \& Joshi, S. (2014). Relationship between Self-Concept and Self-Esteem in Adolescents. International Journal of Advanced Research, 2(2), 36-43. Retrieved from http://www.journalijar.com/article/1331/relationshi p-between-self-concept-and-self-esteem-inadolescents/

Suar, D., Gochhayat, J., \& Suar, J. (2016). Influence of SelfEsteem on Ethical Behaviours and Corporate Responsibility Values: The mediating Role of Power-Distance. Global Business Review, 17(6), 1401-1411. https://doi.org/10.1177/0972150916660405

Tlonaen, Z. A., \& Blegur, J. (2017). Konsep Diri Akademik Mahasiswa Pascasarjana. Scholaria: Jurnal Pendidikan dan Kebudayaan, 7(3), 226-233. DOI 10.24246/j.scholaria.2017.v7.i3.p226-233

Tripathi, N., \& Pandey, S. (2018). Parenting and its Role in the Development of Self-Esteem in Adolescents. The International Journal of Indian Psychology, 6(3), 24-47.

Trzesniewski, K. H., Donnellan, M. B.,Moffitt, T. E., Robins, R. W., Poulton, R.,Caspi, A. (2006). Low SelfEsteem during Adolescence Predicts Poor Health, Criminal Behavior, and Limited Economic Prospects During Adulthood. Developmental Psychology, 42(2), 381-390. http://dx.doi.org/10.1037/0012-1649.42.2.381

Utami, M. S., Praptomojati, A., Wulan, D. L. A., \& Fauziah, Y. (2017). Self-Esteem, Forgiveness, Perception of Family Harmony, and Subjective Well-Being in Adolescents. International Journal of Research Studies in Psychology, 7(1), 59-72.

Valdez, J. C. (2015). Identidad Vocacional, Claridad del Autoconcepto y Autoestima en Adolescentes Peruanos. Psychology, Society, \& Education, 7(1), 23-39. http://dx.doi.org/10.25115/psye.v7i1.538

Wasak, M. R. P., Manggoa, M. A., \& Blegur, J. (2016). Perilaku Indisipliner Mahasiswa dan Implikasinya dalam Proses Belajar-Mengajar. Seminar Nasional Psikologi Indigenous Indonesia 2016 "Kebhinekaan dan Masa Depan Indonesia: Peran Ilmu Sosial dalam Masyarakat (hal. 433-449), Malang, Universitas Negeri Malang.

Wentzel, K. R. (1991). Social Competence at School: Relation between Social Responsibility and Academic Achievement. Review of Educational, 61(1), 1-24. https://doi.org/10.3102/00346543061001001

Yasmin, F. L., Santoso, A., \& Utaya, S. (2016). Hubungan Disiplin dengan tanggung Jawab Siswa. Jurnal Pendidikan: Teori, Penelitian, dan Pengembangan,
$1(4)$, http://dx.doi.org/10.17977/jp.v1i4.6226

692-697.

Zuriah, N. (2007). Pendidikan Moral dan Budi Pekerti dalam Perspektif Perubahan: Menggagas Platform Pendidikan Budi Pekerti secara Kontekstual dan Futuristik. Jakarta: Bumi Aksara. 